\title{
Association between physical and geochemical characteristics of thermal springs and algal diversity in Limpopo Province, South Africa
}

\author{
CZ Jonker ${ }^{1 *}$, C van Ginkel ${ }^{2}$ and J Olivier ${ }^{1}$ \\ ${ }^{1}$ University of South Africa, Department of Environmental Sciences, School of Agriculture and Environmental Sciences, \\ PO Box X6, Florida 1710, South Africa \\ ${ }^{2}$ Cripsis Environment - Environmental Services, $20^{\text {th }}$ Ave, Rietondale, Pretoria, South Africa
}

\begin{abstract}
Algal species commonly occur in thermophilic environments and appear to have very wide geographical distributions. Presence of algal species is strongly influenced by temperature, $\mathrm{pH}$ and mineral content of thermal waters. No research has previously been documented on the algal diversity in South African thermal springs. This paper describes the algal distribution in 6 thermal springs in Limpopo Province, South Africa, and attempts to link this to the physical and geochemical properties of the springs. Water samples were collected from Mphephu, Siloam, Tshipise, Sagole, Eiland and Soutini thermal springs and algae identified. Temperature, $\mathrm{pH}$ and TDS were measured on site and water samples analysed for macro- and trace-elements. Cyanophyta was the algal group most often present, followed by Bacillariophyta, Chlorophyta, Euglenophyta and Dinophyta. Some of the algae were present in waters with $\mathrm{pH}$ ranging from 7.1-9.7 and temperatures ranging from $40-67^{\circ} \mathrm{C}$. Others (the cyanobacteria and green algae: Nodularia, Schizothrix, Anacystis, Coelastrum, Chlorella and Spirogyra) only occurred in high temperature $\left(60+^{\circ} \mathrm{C}\right)$ and $\mathrm{pH}>9$ waters, while a number of diatoms (Synedra, Aulacoseira, Nitzschia, Cyclotella, Gyrosigma, Craticula) occurred exclusively at temperatures $<45^{\circ} \mathrm{C}$ and $\mathrm{pH}$ values $<8$. Algae were also present in waters with fluoride values exceeding that which is considered safe for human consumption as well as in waters relatively rich in uranium, rubidium, vanadium and manganese. It was clear that the occurrence of algae coincided with specific geological formations. These algae could act as indicator species of geology and heavy metals.
\end{abstract}

Keywords: thermal springs, Limpopo Province, algae, diversity, geochemical

\section{Introduction}

Algae are common in water and soil habitats, at different geographic latitudes, and on all continents. They occur in waters with different degrees of salinity, trophicity, organic matter, and hydrogen ions, and at various temperatures. Thermal spring algae communities have long attracted the attention of microbial ecologists because of their unique adaptations to harsh environments (Sompong et al., 2005). Although algae seem to be widespread in thermal waters, some thermophilic organisms have distinctive geographic distribution patterns, with their distribution being limited by their ecological adaptation, resistance and tolerance to extreme environments.

Thermophilic algae include members of the Cyanophyta (blue-green bacteria; cyanobacteria), Chlorophyta (green algae), Bacillariophyta (diatoms), Euglenophyta and Dinophyta. The occurrence of cyanobacteria is especially widespread in thermal environments; with members of the phylum inhabiting thermal springs all over the world (Winterbourn, 1969; Pelczar et al., 1988; Seckbach, 2007). Many species of cyanobacteria have bee isolated from thermal springs in the Yellowstone National Park, from the sulphur hot springs in the Himalayas and from springs in Jordan. The most abundant cyanobacteria genera identified in these thermal springs were Phormidium, Schizothrix, Calothrix, Tolypothrix, Microcystis, Chroococcus, Oscillatoria, Scytonema, Synechococcus,

\footnotetext{
To whom all correspondence should be addressed.

+27 78109 8044; e-mail: jonkecz@unisa.ac.za Received 28 March 2012; accepted in revised form 7 January 2013.
}

Fischerella and Lyngbya (Prasad and Srivastava, 1965; Mann and Schlichting, 1967; Stockner, 1967; Oren et al., 2009). These cyanobacteria appear to be favoured by high temperatures, low light, low nutrient (particularly nitrogen) availability and high predation pressure. Research on diatoms has revealed that Rhopalodia, Denticula, Mastogloia, Navicula, Nitzschia, Pinnularia, Caloneis and Achnanthes are some of the genera found in thermal waters (Stockner, 1967).

The diversity of algae in thermal springs is influenced by the mineral composition and water temperature of the spring (Castenholz, 1969; Sember, 2002; Sompong et al., 2005). Generally, diversity of algal species increases from $0^{\circ} \mathrm{C}$ to $25^{\circ} \mathrm{C}$ and decreases at temperatures $>30^{\circ} \mathrm{C}$, while biomass increases with temperature from approximately 0 to $30^{\circ} \mathrm{C}$ and decreases from 30 to $40^{\circ} \mathrm{C}$ (Dallas, 2008). According to Atlas and Bartha (1987), algae are restricted to growth below $55^{\circ} \mathrm{C}$, while Winterbourn (1969) reported an upper temperature limit for algal growth of $68^{\circ} \mathrm{C}$. Because of the shallowness and clarity of most thermal waters and the exposure of many hot springs to high light intensities, various types of 'sun adaptations' may have occurred in many thermophilic organisms (Castenholz, 1969).

Many algae appear to have adapted to high salinity and/or high concentrations of specific ions. Most alkaline hot springs contain between 1000 and $2000 \mathrm{mg}$ of total dissolved solids (TDS) per litre; some have salinities higher than that of seawater (Castenholz, 1969). Generally, cyanobacteria prefer alkaline environments and exhibit a wide range of tolerance to salinity (Castenholz, 1969; Sember, 2002; Van Ginkel, 2004). Several cyanobacteria species have been isolated from thermal springs in Greece with sodium chloride concentrations of more than 


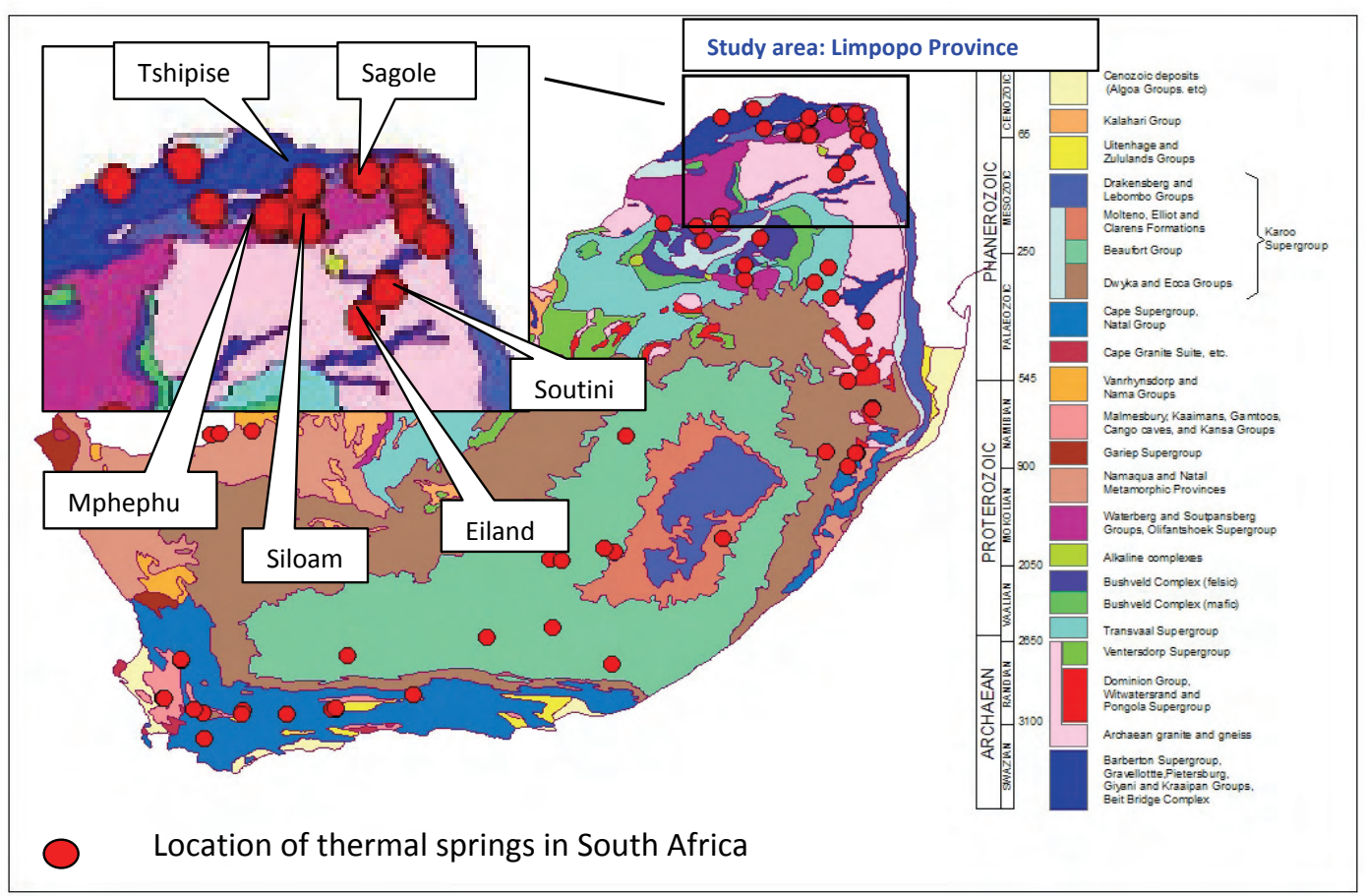

Figure 1

Study areas in Limpopo Province (Olivier et al., 2011)
$15000 \mathrm{mg} / \ell$ (Castenholz, 1969). An abundance of halophilic algae species belonging to the Cyanophyta, Chlorophyta and Bacillariophyta were also noted in the Tiberias hot springs of Israel, where TDS concentrations exceeded $30000 \mathrm{mg} / \ell$ (Rahat and Dor, 1966; Carr and Whitton, 1973).

The extreme heterogeneity of algae makes generalisation about their nutritional requirements difficult. It is alleged that nitrate, phosphate, potassium, magnesium, calcium, sulphur, iron, copper, manganese, molybdenum, sodium, cobalt, vanadium and silica are required for photo-autotrophic algal growth (Provasoli and Pintner, 1960; O'Kelley, 1968). Cobalt, in particular, is known to be required in the inorganic form by some cyanobacteria (O'Kelley, 1968).

The chemical composition of thermal spring waters is influenced by the prevailing geology. Several studies on thermal springs have indicated high concentrations of minerals such as arsenic, fluoride, manganese, iron, aluminium, lithium, silica, fluoride and bromine. Hot waters circulating at depths below the earth's surface will dissolve minerals from the rocks through which they pass. Research on South African thermal springs conducted by Rindle (1916), Kent (1949) and Olivier et al. $(2008,2011)$ revealed various chemical and physical conditions at different sites, including temporary hard carbonate water, oligotrophic waters or water low in mineral content. South Africa has a relatively large number of thermal springs; to date over 70 thermal springs have been identified. Limpopo Province in South Africa has 23 thermal springs - more than any of the other Provinces. Many of the South African hot springs are located on the geologically active Cape Fold Belt, the Namaqua-Natal Belt and the Limpopo Belt (Olivier et al., 2011). None of the springs are volcanic in origin, all being associated with faulting or folding. Studies on the identification of algae in thermal springs and their geochemical distrubition have not previously been documented in South Africa. Knowledge of the association between the geology and algal distribution could facilitate the identification of specific thermal spring niche ecosystems. Conversely, some algae might be able to act as indicators of geology and specific heavy metals.
The aim of this paper is to describe the association between the physical and geochemical characteristics of thermal springs and the occurrence of thermophilic algae in Limpopo Province, South Africa.

\section{Materials and methods}

\section{Site characteristics}

The 6 thermal springs studied are located in 2 regions in the vicinity of the Soutpansberg, in the northern part of the Limpopo Province (Fig. 1). Tshipise, Sagole, Siloam and Mphephu are found in the Soutpansberg Mountains, while Eiland and Soutini are located to the east of the Drakensberg, in the Limpopo lowveld. Eiland and Tshipise have been developed as leisure resorts but the other four springs are located in rural areas.

All South African thermal springs are meteoric in origin, with waters rising to the surface along regional tensional faults. The geology of the study area includes various lithologies of the Soutpansberg Group and Karoo Supergroup, as well as the Goudplaats-Hout River Gneiss Suite and the Beit Bridge Complex (Olivier et al., 2011).

\section{Sampling and analysis}

Field trips were undertaken during August and September 2010 to collect algae samples from 6 thermal springs in the northern part of Limpopo. Algal mat samples (Fig. 2b, 2c) were collected from the sampling sites at Mphepu (Fig. 2a), Siloam, Eiland, Tshiphise, Sagole and Soutini. The thermophilic algae mat was harvested from both hard and soft substrates where these were present. The samples were stored in portable ice chests ("cooler boxes') while being transported to the laboratory for analysis.

\section{Algal identification}

Microscopic observations, for identification purposes only, were conducted within $24 \mathrm{~h}$ of collection of samples at 

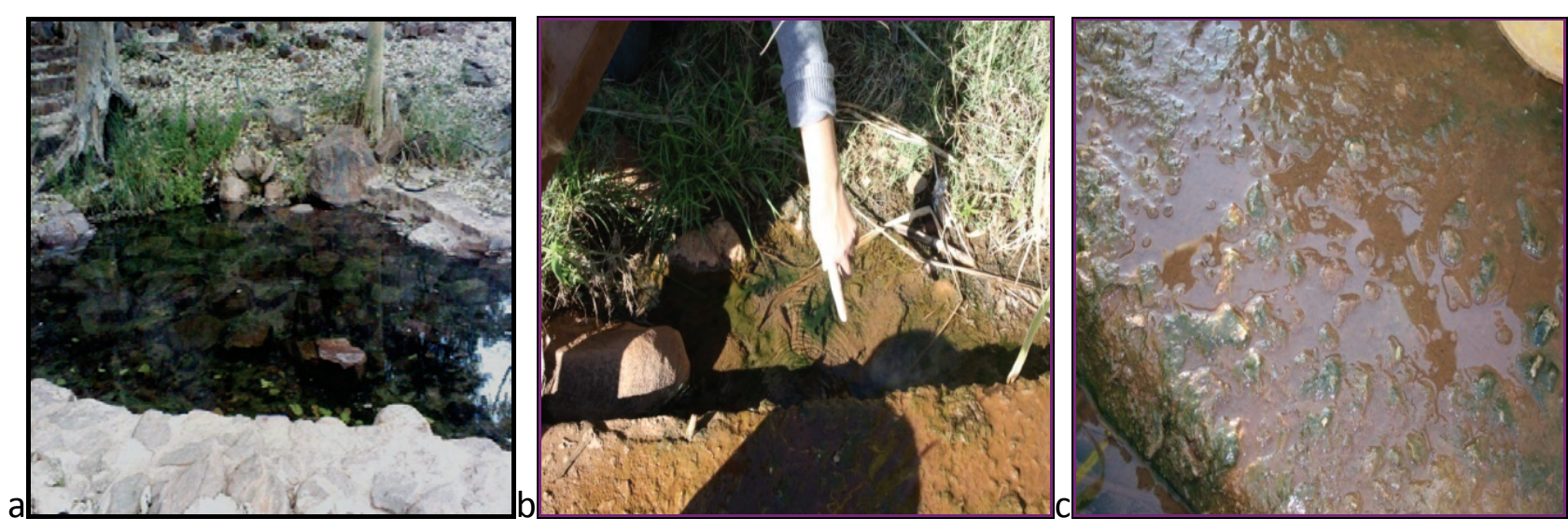

Figure 2

(a) Thermal spring at Mphephu $\left(43^{\circ} \mathrm{C}\right) ;(b, c)$ Mat-forming algae at Siloam thermal spring $\left(67^{\circ} \mathrm{C}\right)$

Resource Quality Services, Department of Water Affairs, Roodeplaat. Algae were identified with a Carl Zeiss inverted light microscope (magnification of 400 or 1000 ). Subsamples were taken until no new species were encountered. Morphological types were identified to the genus level and classification of algae was done using references in literature (Entwisle et al., 1997; Janse Van Vuuren et al., 2006).

\section{Physico-chemical characteristics of the springs}

The source water temperatures were measured as close as possible to the eye of the spring using a temperature probe (Wissenschaftlich-Technische Werkstätten, serial No. 11311570.). The $\mathrm{pH}$ and electrical conductivity (EC) were measured in the field by electrodes - WissenschaftlichTechnische Werkstätten, serial Nos. 11311570 and 09270790 , respectively. Measurements were replicated thrice. Water samples collected from Mphephu, Siloam, Tshipise, Sagole and Eiland in August 2010 were analysed at an accredited laboratory (Institute for Soil, Climate and Water at the Agricultural Research Council)( ARC-ISCW) in Pretoria, while samples from Soutini, collected in September 2010, were analysed by the Council of Geosciences Laboratories. All samples were analysed for trace minerals, including copper, cobalt, zinc, manganese, boron and molybdenum, elements known to be essential micronutrients for blue-green bacteria (Castenholz, 1969). All chemical analyses were carried out by the ARC-ISCW using inductively coupled plasma - atomic emission spectroscopy (ICP-AES). Analyses were conducted on 31 micro-elements.

\section{Results and discussion}

\section{Algal diversity}

Algae in the six thermal springs included a heterogeneous group of unicellular, colonial, mobile and immobile, attached and free-living organisms. Figure 3 gives examples of some of the algae identified in the thermal springs in Limpopo Province, South Africa.

The algae in the 6 hot springs belonged to 5 main divisions of Protista and Monera. The algae found in each hot spring are listed in Table 1. The temperature and $\mathrm{pH}$ of the thermal spring waters are included in Column 1 of Table 1.
Table 1 shows that all six springs contain at least some algae. Oscillatoria were found in all six springs. Anabaena sp. was identified at all springs with the exception of Soutini and Tshipise. The springs lack homogeneity in species distribution, with only the green alga, Oocystis, and the diatoms Cymbella and Navicula occurring in more than one spring. The lowest number of species was found at Eiland and Tshipise. This is not unexpected since these springs have been chlorinated, and it is likely that mixing of the chlorinated water has occurred with the waters from the spring source. At Mphephu and Siloam, the Cyanophyta dominate. A large number of diatoms were found at Sagole and Soutini.

\section{Temperature and $\mathrm{pH}$}

In an attempt to establish the influence of temperature, $\mathrm{pH}$, or a combination of the two, on the distribution of algae, $\mathrm{pH}$ and temperature zones in which the algal genera occur were superimposed to find the best 'fit'. This was found to be in the temperature and $\mathrm{pH}$ ranges of $40-50^{\circ} \mathrm{C}$ and $7.5-8.4$, respectively, as well as at $60+{ }^{\circ} \mathrm{C}$ and $\mathrm{pH}>9$. Table 2 shows the temperature and $\mathrm{pH}$ characteristics in the areas where each of the algal genera was found.

\section{Temperature}

Source water temperatures at the thermal springs in the study area range from $40^{\circ} \mathrm{C}$ to $67.5^{\circ} \mathrm{C}$. Tables 1 and 2 indicate that there was considerable diversity of algae communities in thermal waters with temperatures above $60^{\circ}$. In general, the occurrence of the cyanobacteria were not determined by the thermal characteristics of the springs, since a number of genera, such as Oscillatoria, Anabaena, Phormidium, Nostoc and Lyngbya were found in springs with temperatures ranging from $40^{\circ} \mathrm{C}$ to $60+^{\circ} \mathrm{C}$. Phormidium sp. dominated the $60+{ }^{\circ} \mathrm{C}$ temperature zone, while Oscillatoria sp. was distributed across the entire temperature range $\left(40\right.$ to $\left.67.5^{\circ} \mathrm{C}\right)$. Similar acclimatisation to high temperatures is found amongst some of the green algae. Oocystis sp., Coelastrum sp., Chlorella sp. and Spirogyra $\mathrm{sp}$. were identified in waters with temperatures exceeding $60^{\circ} \mathrm{C}$. With the exception of 2 genera, Pinnularia and Cocconeis, the diatoms seem to prefer lower temperatures. However, temperature per se does not appear to be a limiting factor in the distribution of algae. 


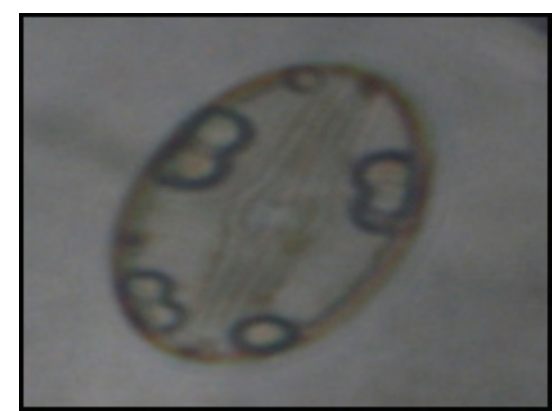

$A(a)$

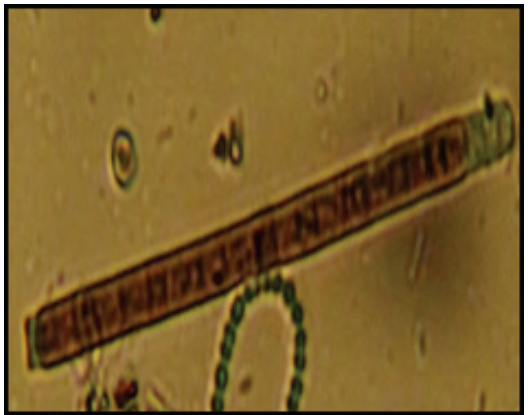

$B(a)$

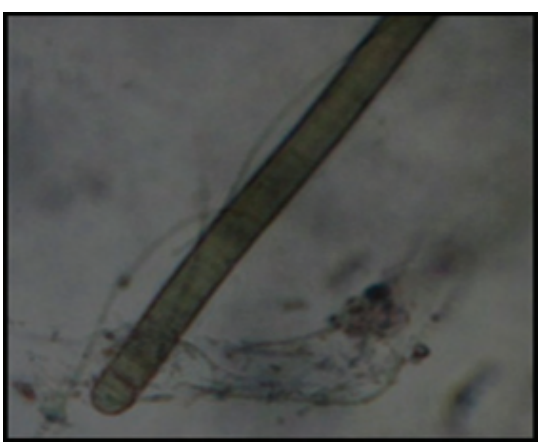

$B(d)$

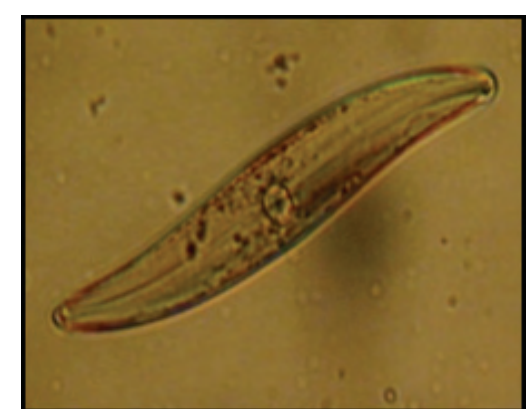

$A(b)$

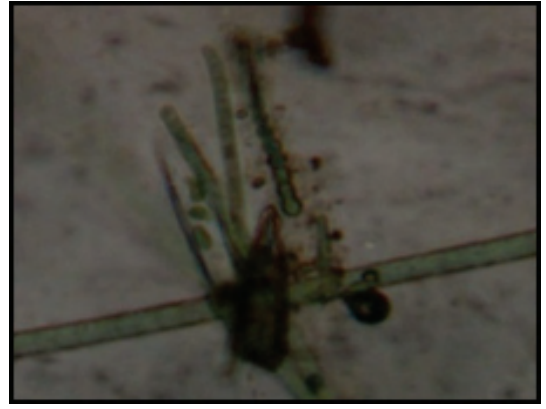

B(b)

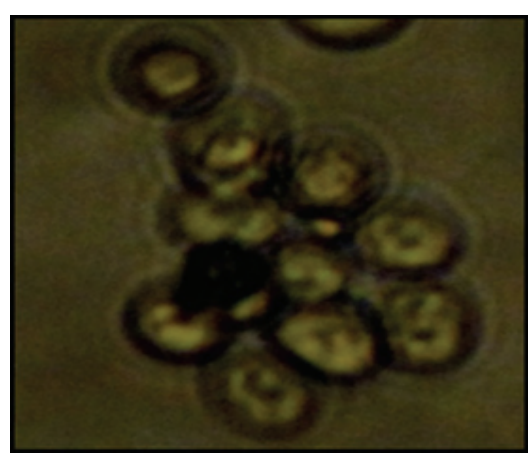

C(a)

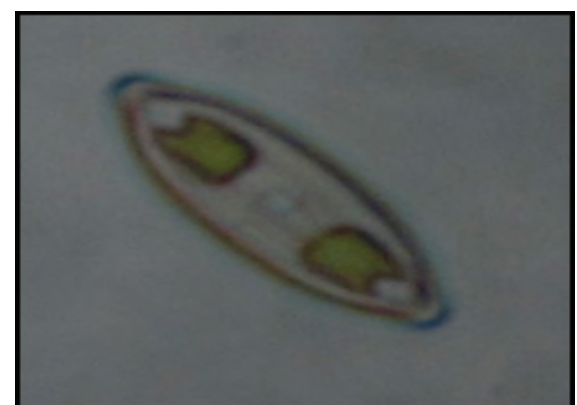

A(c)

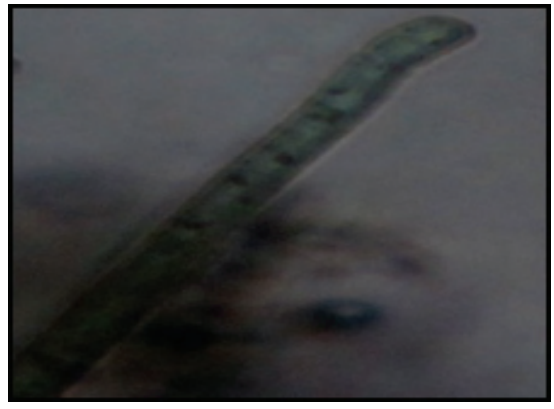

$B(c)$

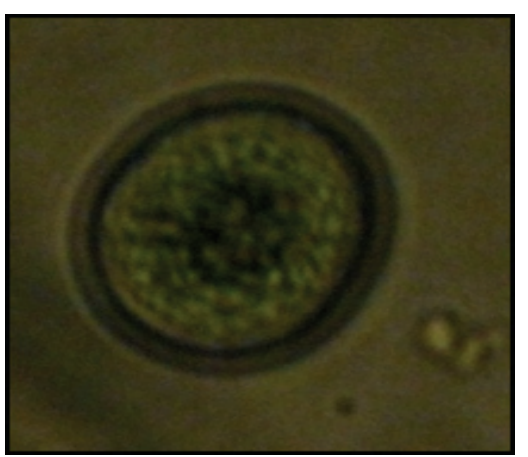

C(b)

Figure 3

Some algae from hot springs in northern Limpopo Province

A Bacillariophyta

(a) Cyclotella kutzing sp. Cells are 5-30 $\mu \mathrm{m}$ in diameter, a common planktonic diatom

found throughout the world, widespread in brackish water (Janse Van Vuuren et al., 2006)

(b) Gyrosigma hassall sp. Cells are 60-400 $\mu \mathrm{m}$ long and 11-40 $\mu \mathrm{m}$ wide. Species within this genus are often found in dense algal mats on the bottom of lakes. Genus may be found in brackish water (Janse Van Vuuren et al., 2006)

(c) Craticula grunow sp. Cells are 9.5-170 $\mu \mathrm{m}$ long and 3-35 $\mu \mathrm{m}$ wide, species tend to be associated with fresh to brackish waters (Janse Van Vuuren et al., 2006).

B Cyanophyta

(a) Lyngbya agardh ex Gomont sp. Diameter of trichomes varies from 1-30 $\mu$ m, inhabits fresh and brackish water. Lyngbya sp. has a firm, rigid sheet (Janse Van Vuuren et al., 2006). Anterior cells have thickened terminal cap (Entwisle et al., 1997).

(b) Nostoc sp.

(c) Phormidium sp. (Entwisle et al., 1997; Janse Van Vuuren et al., 2006).

(d) Oscillatoia sp. (Entwisle et al., 1997).

C Chlorophyta

(a) Coelastrum nageli sp. (Janse Van Vuuren et al., 2006).

(b) Chlamydomonas sp. (Janse Van Vuuren et al., 2006).

\section{pH}

Waters of most of the thermal springs in the study area are alkaline $(\mathrm{pH}>8)$, with the exception of Eiland and Soutini which have $\mathrm{pH}$ values in the neutral zone (Table 1). According to literature, (Castenholz, 1969; Sember, 2002; Van Ginkel, 2004) cyanobacteria prefer alkaline environments. It was thus not unexpected that mat communities at Siloam $(\mathrm{pH}=$ 9.5) and Sagole $(\mathrm{pH}=9.94)$ had the highest cyanobacterial presence. Tables 1 and 2 indicate that Oscillatoria, Anabaena, Phormidium, Nostoc and Lyngbya thrive in waters with $\mathrm{pH}$ ranging from 7.5 to $>9$; however, Nodularia, Schizothrix and Anacystis occurred in highly alkaline waters $(\mathrm{pH}>9)$ in this 


\begin{tabular}{|c|c|c|c|c|c|}
\hline \multicolumn{6}{|c|}{$\begin{array}{l}\text { Table } 1 \\
\text { Algal presence at selected thermal springs in Limpopo Province }\end{array}$} \\
\hline $\begin{array}{l}\text { NAME } \\
T=\text { Temp. }\left({ }^{\circ} \mathrm{C}\right)\end{array}$ & $\begin{array}{l}\text { Cyanobacteria } \\
\text { (Cyanophyta) }\end{array}$ & $\begin{array}{l}\text { Green algae } \\
\text { (Chlorophyta) }\end{array}$ & $\begin{array}{l}\text { Diatoms } \\
\text { (Bacillariophyta) }\end{array}$ & $\begin{array}{l}\text { Euglenoids } \\
\text { (Euglenophytha) }\end{array}$ & $\begin{array}{l}\text { Dinoflagellates } \\
\text { (Dinophyta) }\end{array}$ \\
\hline $\begin{array}{l}\text { Mphephu } \\
T=43 \\
\text { pH }=8.1\end{array}$ & $\begin{array}{l}\text { Oscillatoria sp. } \\
\text { Anabaena sp. } \\
\text { Phormidium sp. } \\
\text { Nostoc sp. } \\
\text { Lyngbya sp. } \\
\end{array}$ & Kirchneriella sp. & Diadesmus sp. & & \\
\hline $\begin{array}{l}\text { Eiland } \\
T=40.1 \\
\mathrm{pH}=7.6\end{array}$ & Anabaena sp. & & & & \\
\hline $\begin{array}{l}\text { Sagole } \\
T=45 \\
\mathrm{pH}=9.7\end{array}$ & $\begin{array}{l}\text { Anabaena sp. } \\
\text { Oscillatoria sp. }\end{array}$ & Oocystis sp. & $\begin{array}{l}\text { Cymbella sp. } \\
\text { Surirella sp. } \\
\text { Pinnularia sp. } \\
\text { Navicula sp. }\end{array}$ & Euglena sp. & \\
\hline $\begin{array}{l}\text { Siloam } \\
T=67 \\
\mathrm{pH}=9.5\end{array}$ & $\begin{array}{l}\text { Phormidium sp. } \\
\text { Anacystis sp. } \\
\text { Oscillatoria sp. } \\
\text { Nostoc sp. } \\
\text { Nodularia sp. } \\
\text { Schizothrix sp. } \\
\text { Anabaena sp. } \\
\text { Lyngbya sp. }\end{array}$ & $\begin{array}{l}\text { Oocystis sp. } \\
\text { Coelastrum sp. } \\
\text { Chlorella sp. } \\
\text { Spirogyra sp. }\end{array}$ & Cocconeis sp. & & Peridinium sp. \\
\hline $\begin{array}{l}\text { Soutini } \\
T=40 \\
\mathrm{pH}=7.8\end{array}$ & Oscillatoria sp. & $\begin{array}{l}\text { Scenedesmus sp. } \\
\text { Chlamydomonas sp. } \\
\text { Coelastrum sp. } \\
\text { Closterium sp. }\end{array}$ & $\begin{array}{l}\text { Cymbella sp. } \\
\text { Pinnularia sp. } \\
\text { Navicula sp. } \\
\text { Aulacoseira sp. } \\
\text { Nitzschia sp. } \\
\text { Cyclotella sp. } \\
\text { Gyrosigma sp. } \\
\text { Craticula sp. } \\
\text { Synedra sp. }\end{array}$ & & \\
\hline $\begin{array}{l}\text { Tshipise } \\
T=58 \\
\mathrm{pH}=8.9\end{array}$ & Oscillatoria sp. & & Pinnularia sp. & Trachelomonas sp. & \\
\hline
\end{tabular}

study area. The same adaptation to high $\mathrm{pH}$ values is true of the green algae Oocystis, Coelastrum, Chlorella and Spirogyra; the diatoms, Cocconeis; and the dinoflaggelate, Peridinium. By contrast, the green algae, Scenedesmus and Chlamydomonas, in the study areas and most of the diatoms (Synedra, Aulacoseira, Nitzschia, Cyclotella, Gyrosigma and Craticula) are confined to $\mathrm{pH}$ neutral water ( $\mathrm{pH} 7-8)$. In this study area the diatoms Cymbella, Pinnularia and Navicula did not seem to occur preferentially at any particular $\mathrm{pH}$ values.

\section{Combination of thermal and $\mathrm{pH}$ conditions}

An interesting picture that emerges from Table 2 is that certain algae are confined to specific temperature-pH value conditions. During this study, Nodularia, Schizothrix, Anacystis, Coelastrum, Chlorella, Spirogyra, Cocconeis and Peridium were specific to high-temperature, highly-alkaline conditions while Scenedesmus, Closterium, Chlamydomonas, Synedra, Aulacoseira, Nitzschia, Cyclotella, Gyrosigma and Craticula seem not to be able to survive at temperatures and $\mathrm{pH}$ values exceeding $44^{\circ} \mathrm{C}$ and 7.9 , respectively.

\section{Geochemical characteristics}

The main source of nutrients for algal growth in thermal waters would be in the form of dissolved cations and anions, the occurrence of which is dependent on the geochemical mineral content of the thermal water. Table 3 provides the concentrations of selected macro- and micro-elements found in the six thermal springs.

Sodium, potassium, magnesium and calcium, as well as nitrates, phosphates and sulphates, were present in very low concentrations in all springs, except for Eiland and Soutini. High sulphate levels were measured at Eiland (143.63 mg/ $\ell$ ) and Soutini $(759 \mathrm{mg} / \ell)$, while maximum sulphate concentration recorded at most other springs were $53 \mathrm{mg} / \ell$ or less (Table 3). Nitrate concentrations were negligible, except at Eiland, Soutini and Mphephu. Phosphates were absent or present at very low concentrations in the source waters of all springs, with the exception of Eiland.

Table 3c indicates the concentration of trace elements at the springs. It is noticeable that the concentrations of boron were low $(<60 \mu \mathrm{g} / \ell)$ at Sagole, Siloam and Mphephu, but much higher (more than $200 \mu \mathrm{g} / \ell$ ) at Tshipise and Eiland. Nickel levels were also high at Tshipise. Most of the other trace elements were considerably higher at Eiland and Soutini, mirroring the pattern of the macro-element concentrations. The trace elements necessary for algal growth, namely, copper, molybdenum, manganese, cobalt and vanadium, are found at 


\begin{tabular}{|c|c|c|c|c|c|}
\hline \multicolumn{6}{|c|}{$\begin{array}{c}\text { Table } 2 \\
\text { Temperature and pH ranges for algal genera }\end{array}$} \\
\hline $\begin{array}{l}\text { Temperature }\left({ }^{\circ} \mathrm{C}\right) \\
\mathrm{pH}\end{array}$ & \begin{tabular}{|l|}
$40-44$ \\
$7.5-7.9$
\end{tabular} & \begin{tabular}{|l|}
$45-49$ \\
$8.0-8.4$
\end{tabular} & \begin{tabular}{|l|}
$50-54$ \\
$8.5-8.9$
\end{tabular} & $55-59$ & $\begin{array}{l}60+ \\
9.0-9.9\end{array}$ \\
\hline \multicolumn{6}{|c|}{ Blue-green bacteria } \\
\hline Oscillatoria & * & $* \quad$ & * & & * \\
\hline \multicolumn{6}{|l|}{ Anabaena } \\
\hline \multicolumn{6}{|l|}{ Phormidium } \\
\hline \multicolumn{6}{|l|}{ Nostoc } \\
\hline \multicolumn{6}{|l|}{ Lyngbya } \\
\hline \multicolumn{6}{|l|}{ Nodularia } \\
\hline \multicolumn{6}{|l|}{ Schizothrix } \\
\hline Anacystis & & & & & \\
\hline \multicolumn{6}{|l|}{ Green algae } \\
\hline Kirchneriella & & $*$ & & & \\
\hline \multicolumn{6}{|l|}{ Oocystis } \\
\hline \multicolumn{6}{|l|}{ Coelastrum } \\
\hline \multicolumn{6}{|l|}{ Chlorella } \\
\hline Spirogyra & & & & & $*$ \\
\hline \multicolumn{6}{|l|}{ Scenedesmus } \\
\hline \multicolumn{6}{|l|}{ Chlamydomonas } \\
\hline \multicolumn{6}{|l|}{ Diatoms } \\
\hline \multicolumn{6}{|l|}{ Diadesmus } \\
\hline Cymbella & $*$ & & & & $*$ \\
\hline Surirella & & & & & * \\
\hline Pinnularia & $*$ & & $*$ & & * \\
\hline Navicula & $*$ & & & & * \\
\hline Cocconeis & & & & & $*$ \\
\hline \multicolumn{6}{|l|}{ Synedra } \\
\hline \multicolumn{6}{|l|}{ Aulacoseira } \\
\hline \multicolumn{6}{|l|}{ Nitzschia } \\
\hline \multicolumn{6}{|l|}{ Cyclotella } \\
\hline \multicolumn{6}{|l|}{ Gyrosigma } \\
\hline \multicolumn{6}{|l|}{ Craticula } \\
\hline \multicolumn{6}{|l|}{ Euglenoids } \\
\hline Euglena & & & & & $*$ \\
\hline Trachelomonas & & & * & & \\
\hline \multicolumn{6}{|l|}{ Dinoflagellates } \\
\hline Peridinium & & & & & $*>$ \\
\hline
\end{tabular}

(diatoms) occur exclusively at Soutini (Table 1).

Although the inorganic composition of the six thermal spring waters may influence the composition of the algal ecosystems, patterns were difficult to distinguish. For this reason, the possible association between the underlying geology and the algal composition of the springs was investigated.

\section{Geology}

Table 4 provides a summary of the prevailing geology at surface and depth at the springs.

Olivier et al. $(2008,2011)$ showed that the mineral composition of the thermal waters probably reflects the geological formations that occur at the depth of origin of the thermal spring water rather than surface geology. Therefore the type of rock occurring at the surface of the earth does not necessarily influence the chemical composition of thermal spring waters.

Mphephu and Siloam both occur within the Soutpansberg Group. Mphephu is a feature of the Wyllie's Poort and Nzhelele Formations while, barely $5 \mathrm{~km}$ from Mphephu, the thermal spring at Siloam is underlain by basaltic lava of the Sibasa Formation (Olivier et al., 2011). Potassium $\left(\mathrm{Mg}^{2+}\right)$ and calcium $\left(\mathrm{Ca}^{2+}\right)$ may be associated with basaltic intrusions. These ions are also present in higher concentrations in waters from Mphephu than in those from Siloam and might derive from sandstones, quartzites and some basaltic intrusions.

Even though Tshipise and Sagole are geographically far apart, both of these thermal springs are underlain by rocks of the Karoo Supergroup. Sagole is underlain by sedimentary rocks of the Mikambeni Formation and Madzaringwe Formation, while Tshipise is underlain by volcanic rocks of the Letaba Formation. Sagole is associated with micaceous sandstone, siltstone and shale (Johnson et al., 2006). The Letaba Formation immediately underlying the spring at Tshipise comprises mainly basalt with minor andesite and sandstone. The spring also lies close to a dolerite intrusion. Compared to the other springs, the waters of Tshipise and Sagole are relatively poor in magnesium.

The underlying geology at Eiland (Letaba) and Soutini is grey biotite gneiss and micmatite and Eiland (and Soutini) are underlain by the Goudplaats-Hout River Gneiss Suite, which can explain the high potassium levels in these waters. Little is known about the geology at Soutini, but in view of the chemical characteristics of the waters it is probably similar to that of Eiland. Most of the ions in the Eiland hot spring could have been acquired from the granite, and, to a lesser degree, the diabase and basic rocks such as amphibolites present in the granite. These springs (Eiland and Soutini) are saline and have extremely high concentrations of sodium, potassium, calcium, chloride and sulphate, as indicated by TDS values exceeding $1500 \mathrm{mg} / \ell$. The sodium $\left(\mathrm{Na}^{+}\right)$concentrations at the springs, with the exception of Eiland, probably originate from quartz and sodium-rich plagioclase feldspars from the sandstones and shales.

Certain algae are characteristic of specific geochemical environments. Figure 3 attempts to illustrate the possible relationship between the geology at depth (and therefore the mineral content of the water) and the distribution of algae.

Only Oscillatoria was found in all spring waters. Cyanophyta (cyanobacteria) were more prevalent in waters from Mphephu, and in the basaltic waters from Siloam, than at any of the other springs. The Cyanophytes, (Phormidium, Nostoc, Lyngbya, Nodularia, Schizothrix and Anacystis) were only present in springs underlain by the Soutpansberg Group, i.e. at Mphephu and Siloam (Group A in Fig. 3). 


\begin{tabular}{|c|c|c|c|c|c|c|}
\hline \multicolumn{7}{|c|}{$\begin{array}{c}\text { Table } 3 \\
\begin{array}{c}\text { Physical and chemical constitution of thermal springs in the study area (from Olivier et al., 2011) } \\
\text { Relatively high concentrations of elements are in bold. }\end{array}\end{array}$} \\
\hline & Mphephu & Siloam & Sagole & Tshipise & Eiland & Soutini \\
\hline Temperature $\left({ }^{\circ} \mathrm{C}\right)$ & 43 & 67.5 & 45 & 58 & 42 & 40.1 \\
\hline $\mathrm{pH}$ & 8.08 & 9.51 & 9.70 & 8.85 & 7.63 & 7.81 \\
\hline TDS $(\mathrm{mg} / \ell)$ & 199.36 & 197.3 & 39.0 & 460.56 & 1937.2 & 1510.0 \\
\hline Conductivity (mS/m) & 44.0 & 39.0 & 39.0 & 81.0 & 230.0 & 297.0 \\
\hline \multicolumn{7}{|l|}{ a) Cations (mg/e) } \\
\hline Sodium & 44.37 & 66.24 & 65.15 & 156.31 & 621.88 & 3487.34 \\
\hline Potassium & 1.14 & 2.82 & 1.10 & 4.25 & 21.79 & 31.13 \\
\hline Calcium & 13.73 & 1.40 & 1.31 & 5.58 & 53.61 & 240.23 \\
\hline Magnesium & 11.25 & 1.30 & 0.07 & 0.17 & 9.37 & 80.89 \\
\hline \multicolumn{7}{|l|}{ b) Anions (mg/e) } \\
\hline Fluoride & 3.16 & 6.11 & 1.0 & 5.63 & 2.24 & 8 \\
\hline Nitrate & 2.12 & 0 & 0 & 0.61 & 2.69 & 2.5 \\
\hline Chloride & 39.38 & 44.35 & 47.85 & 168.97 & 982.62 & 5523 \\
\hline Sulphate & 9.26 & 2.69 & 18.20 & 53.17 & 143.63 & 759 \\
\hline Phosphate & 0 & $0-2.69$ & 0 & 0 & 24.86 & $<2.5$ \\
\hline Carbonate & 0 & $0-14.40$ & 18.0 & 6.0 & 0 & n.a. \\
\hline \multicolumn{7}{|c|}{ c) Selected trace elements $(\mu \mathrm{g} / \ell)$} \\
\hline Copper & 0 & 0 & 0 & 0 & 3.61 & 68 \\
\hline Cobalt & 0 & 0.05 & 0.01 & 0.10 & 2.07 & 2 \\
\hline Manganese & 0 & 0.75 & 0.20 & 0 & 3.13 & 408 \\
\hline Molybdenum & 0.91 & 2.23 & 1.06 & 1.41 & 3.74 & n.a. \\
\hline Boron & 45.92 & 57.91 & 56.48 & 200.60 & 267.60 & 10 \\
\hline Zinc & 1.95 & 3.46 & 2.05 & 2.48 & 1738 & $<300$ \\
\hline Iodine & 3.25 & 93.14 & 6.41 & 115.20 & 4111.0 & n.a. \\
\hline Selenium & 0 & 0 & 0.20 & 2.35 & 2.83 & 101 \\
\hline Nickel & 0 & 0 & 0 & 37.19 & 2.83 & $<50$ \\
\hline Vanadium & 10.64 & 2.30 & 0.42 & 1.81 & 60.86 & 117 \\
\hline Silica & n.a. & n.a. & n.a. & n.a. & 39878 & 57022 \\
\hline Rubidium & n.a. & n.a. & n.a. & n.a. & 130 & 102 \\
\hline Uranium & 0.45 & 0 & 0 & 0 & 8.53 & 24 \\
\hline
\end{tabular}

Table 4

Geology and geological structures associated with thermal springs in the northern part of Limpopo (Olivier et al., 2011)

\begin{tabular}{|l|l|l|}
\hline Sampling site & Description of surface geology & Lithostratigraphic unit \\
\hline Mphephu* & Sandstone and quartzite & Wyllie's Poort and Nzhelele Formations, Soutpansberg Group \\
\hline Siloam* & Basalt, minor tuff & Sibasa Formation, Soutpansberg Group \\
\hline Tshipise* & $\begin{array}{l}\text { Basalt, minor andesite } \\
\text { Cream } \\
\text { Scoured sandstone } \\
\text { Dolerite sills and dykes }\end{array}$ & $\begin{array}{l}\text { Letaba Formation, Lebombo Group, Karoo Supergroup } \\
\text { Tshipise Member, Clarens Formation, Karoo Supergroup } \\
\text { Karoo dolerite }\end{array}$ \\
\hline Sagole* & $\begin{array}{l}\text { Mudstone, shale, subordinate micaceous sandstone } \\
\text { Shale, carbonaceous shale, siltstone, micaceous } \\
\text { sandstone }\end{array}$ & $\begin{array}{l}\text { Mikambeni Formation } \\
\text { Madzaringwe Formation, Karoo Supergroup }\end{array}$ \\
\hline Eiland** & Leucocratic biotite gneiss & Goudplaats - Hout River Gneiss Suite \\
\hline
\end{tabular}

(According to the Geological Survey: 1:250 000 Messina* and Tzaneen** Map sheets)

Interestingly, the Euglenoids are exclusive to waters from Sagole and Tshipise, which has circulated through sandstonerocks of the Karoo Supergroup (Group B in Fig 3)-, rich in a calcite-type geological formation. Conversely, diatoms Synedra, Aulacoseira, Nitzschia, Cyclotella, Gyrosigma and Craticula, and the green algae Scenedesmus, Closterium and Chlamydomonas, are characteristic of the Goudplaats-Hout
River Gneiss Suite (Group C).

The thermal springs at Eiland and Tshipise are used as tourist resorts. At these resorts the thermal sources are enclosed and thermal waters are chlorinated. The development and chlorination of these spring waters may have created ecological niche communities for algae, such as Anabanea sp. at Eiland and Oscillatoria sp. at Tshipise (Fig. 4). 
Geological distribution of algae $A=$ Mphephu and Siloam; $B=$ Tshipise and Sagole; $C=$ Eiland and Soutini

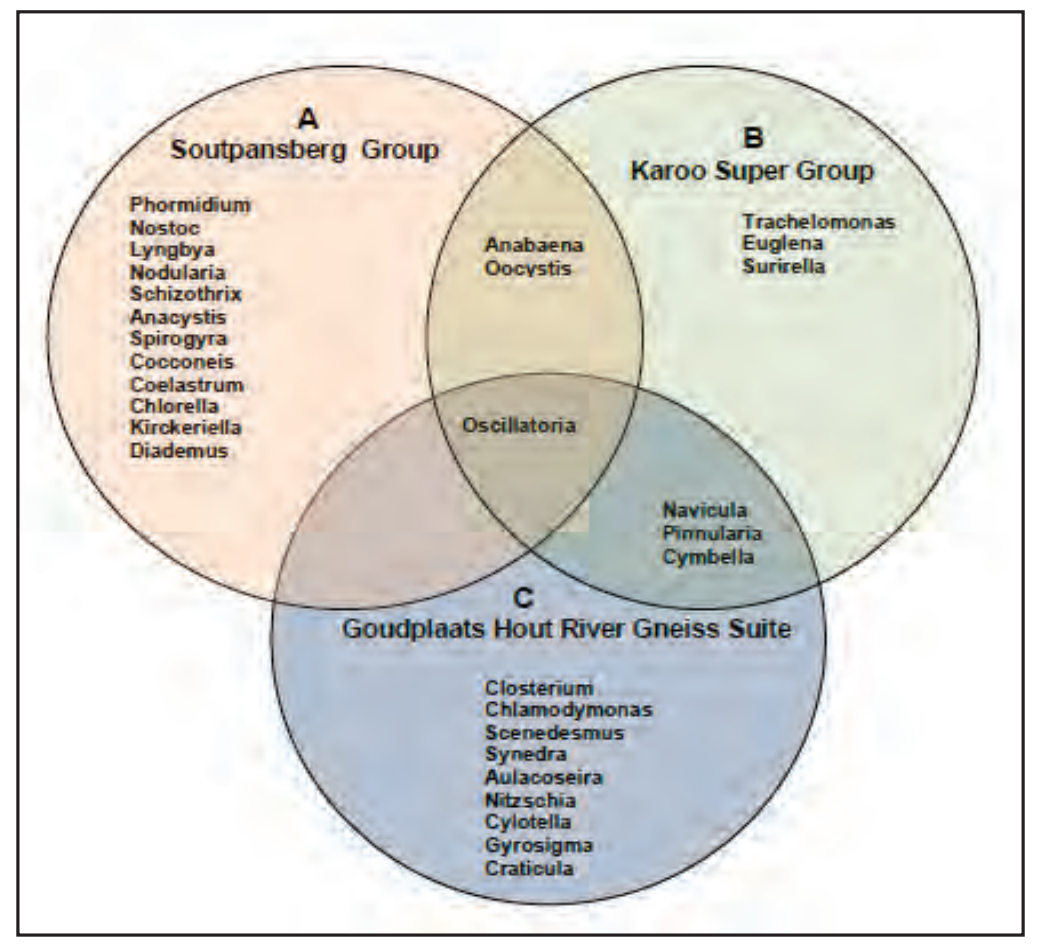

\section{Conclusions}

This study aimed to assess the algal diversity in thermal springs in Limpopo Province, to give insight into the occurrence, distribution and external factors influencing specific genera in hot spring waters in South Africa. Thermal waters of 6 sites, namely, Mphephu, Siloam, Sagole, Tshipise and Soutini, were analysed for physical and geochemical properties that may influence species diversity within these thermal waters. The results offer a perspective on the algal biodiversity of mineral waters.

Morpho-typical analysis revealed a limited diversity of phytoplankton groups. Algae from 5 different phyla, namely Cyanobacteria (cyanobacteria), Bacillariophyta, Chlorophyta, Euglenophyta and Dinophyta were identified from the selected thermal springs, with Cyanobacteria (cyanobacteria) most often present in the selected thermal springs.

There was a high degree of specificity of algal taxa with regard to the geochemical environment. Variations in temperature, $\mathrm{pH}$ and geochemistry of the lithostratigraphic units appear to be the governing determinant in algal distribution for the study area. Results confirm the role that various minerals play in the geo-chemical distribution of algae in thermal springs.

Geochemically, blue-green algae dominated the water of the Soutpansberg Group. It was noticeable that algae in the Soutpansberg Group are adapted to scalding alkaline waters with $\mathrm{pH}$ values exceeding 9 and temperatures exceeding $60^{\circ} \mathrm{C}$. Euglenoids occur in springs underlain by rocks of the Karoo Supergroup. Most of the algae in springs originating in the Karoo Super Group seem to prefer a narrow range of conditions, i.e., neutral $\mathrm{pH}$ waters $(\sim 8)$ with temperatures of $40-50^{\circ} \mathrm{C}$; whereas the diatoms span springs arising in the Karoo Supergroup and the gneisses of the Goudplaats-Hout River Suite. The algae found in springs in the Goudplaats-Hout River Suite can be classified as thermohalophiles.

The community distribution of algae in the selected springs thus suggests not only the influences of geographical isolation due to mineral content, but, also the probable influence of human activity on species dominance in these environments. Recreational or industrial interference in ecosystems of thermal springs may alter the natural biodiversity and promote the production of neurotoxic-forming cyanobacterial isolates such as Oscillatoria, with consequential health-risk implications to users.

\section{Acknowledgements}

This research was supported through a grant from the Water Research Commission (WRC Project K5/1959/1). The authors thank the Department of Water Affairs for assistance with the analysis of the samples and the Hot Water Spring (HWS) team members for their involvement and support during field trips.

\section{References}

ATLAS RM and BARTHA R (1987) Microbial Ecology ( $2^{\text {nd }}$ edn.). The Benjamin Publishing Company, Menlo Park, California.

CARR N and WHITTON B (1973) The Biology of Blue-Green Algae. Botanical Monographs Volume 9. University of California Press, Berkeley.

DALLAS H (2008) Water temperature and riverine ecosystems: An overview of knowledge and approaches for assessing biotic responses, with special reference to South Africa. Water SA 34 (3) 393-404.

ENTWISLE T, SONNEMAN J and LEWIS S (1997) Freshwater Algae in Australia. A Guide to Conspicuous Genera. Sainty and Associates Pty. Ltd., Potts Point.

JANSE VAN VUUREN S, TAYLOR J, GERBER A and VAN GINKEL C (2006) Easy Identification of the Most Common Freshwater Algae. North-West University, Potchefstroom.

JOHNSON MR, VAN VUUREN CJ, VISSER JNJ, COLE DI, WICKENS H DE V, CHRISTIE ADM, ROBERTS DL and BRANDL G (2006) Sedimentary rocks of the Karoo Supergroup. In: Johnson MR, Anhaeusser CR and Thomas RJ (eds) The Geology of South Africa. Geological Society of South Africa, Council for Geoscience, Pretoria. 461-499. 
KENT LE (1949) The thermal waters of the Union of South Africa and South West Africa. Trans. Geol. Soc. S. Afr. 52 231-264.

MANN J and SCHLICHTING J (1967) Benthic Algae of Selected Thermal Springs in Yellowstone National Park. Blackwell Publishing, Oxford.

MUR L, SKULBERG O and UTKILEN H (1999) Cyanobacteria in the environment. In: Chorus I and Bartram J (eds.) Toxic Cyanobacteria in Water. E \& FN Spon/Springer-Verlag KG, London. 15-40.

O’KELLEY J (1968) Mineral nutrition of algae. Annu. Rev. Plant Physiol. 19 89-112.

OLIVIER J, VAN DER WALT I J and VAN NIEKERK H J (2008) Physical and chemical characteristics of thermal springs in the Waterberg area in Limpopo Province, South Africa. Water SA 34 (2) 163-174.

OLIVIER J ,VENTER J and JONKER C (2011) Thermal and chemical characteristics of hot water springs in the northern part of the Limpopo Province, South Africa. Water SA 37 (4) 427-436.

OREN A, IONESCU D, HINDIYEH M and MALKAWI H (2009) Morphological, phylogenetic and physiological diversity of cyanobacteria in the hot springs of Zerka Ma'in, Jordan. BioRisk 3 69-82.

PROVASOLI L and PINTNER I J (1960) Artificial media for freshwater algae: problems and suggestions. In: The Pymatuning symposia in ecology: the ecology of algae, Pymatuning Laboratory of Field Biology. Univ. Pittsburgh Special Publ. 2 84-96.
PELCZAR J, CHAN ECS and KRIEG NR (1988) Microbiology. McGraw-Hill Book Co., Singapore.

PRASAD B and SRIVASTAVA N (1965) Thermal algae from Himalayan hot springs. Proc. Inst. Sci. India 31 (1-2) 45-53.

RAHAT M and DOR I (1966) The hidden flora of a lake. Hydrobiologia 31 (2) 186-192.

RINDL MR (1916) The Medicinal Springs of South Africa (Supplement). S. Afr. J. Sci. 13 528-552.

SECKBACH J (2007) Algae and Cyanobacteria in Extreme Environments. Springer, Dordrecht.

SEMBER C (2002) The effect of nutrient levels and ratios on the growth of Microcystis aeruginosa and microcystin production. Unpublished Masters dissertation, University of Port Elizabeth. SOMPONG U, HAWKINS P, BESLEY C and PEERAPORNPISAL $Y$ (2005) The distribution of cyanobacteria across physical and chemical gradients in hot springs in northern Thailand. FEMS Microbiol. 52 (3) 365-376.

STOCKNER JG (1967) Observations of thermophilic algal communities in Mount Rainier and Yellowstone National Park. Limnol. Oceanogr. 12 (1) 13-17.

VAN GINKEL C (2004) A National survey of the incidence of cyanobacterial blooms and toxin production in major impounds. Department of Water Affairs and Forestry, Pretoria.

WINTERBOURN M (1969) The distribution of algae and insects in hot spring thermal gradients at Waimangu, New Zealand. N.Z. J. Mar. Freshwater Res. 3 (3) 459-465. 
http://dx.doi.org/10.4314/wsa.v39i1.10 Available on website http://www.wrc.org.za

ISSN 0378-4738 (Print) = Water SA Vol. 39 No. 1 January 2013 ISSN 1816-7950 (On-line) = Water SA Vol. 39 No. 1 January 2013 